\title{
Assessment of marginal fit and the match of crowns made of various materials in the CAD/CAM technology to the abutment tooth
}

\section{Ocena szczelności brzeżnej i dopasowania koron wykonanych z różnych materiałów w technologii CAD/CAM}

\section{Daniel Surowiecki}

Katedra Protetyki Stomatologicznej, Warszawski Uniwersytet Medyczny

Department of Prosthetic Dentistry, Medical University of Warsaw

Head: prof. dr hab. n. med. Jolanta Kostrzewa-Janicka

KEY WORDS:

marginal fit, reverse engineering, prosthetic crowns

\section{Summary}

Introduction. Reverse engineering is the process of examining physical, real objects by introducing them into a virtual environment. It can be applied to inspect prosthetic restorations before their cementation.

Aim of the study. To assess the marginal fit of prosthetic restorations made in vitro.

Material and methods. The research material consisted of the substructures of prosthetic crowns, divided into three groups depending on the material used: Group I-three $\mathrm{ZrO}_{2}$ crowns, Group II - three CoCr alloy crowns, Group III - three PMMA crowns. The abutment tooth model and the models of the internal surfaces of the crowns were transferred to the measurement software. The next step was to analyse the accuracy of fitting the entire inner surface of the crowns with the original model.

Results. In Group I, the lowest standard deviation was obtained $(0.02 \mathrm{~mm})$, but the space for the cement turned out to be much larger than the designed space (mean $0.09 \mathrm{~mm}$ ). Group II was characterized by the mean closest to the assumed one, but its differentiation was clearly greater than in the case of Group I. For Group III, the
HASŁA INDEKSOWE: szczelność brzeżna, odwrotna inżynieria, korony protetyczne

\section{Streszczenie}

Wprowadzenie. Odwrotna inżynieria jest procesem badania fizycznych, rzeczywistych przedmiotów poprzez ich wprowadzenie do środowiska wirtualnego. Zastosowaniem odwrotnej inżynierii może być kontrola wykonanych uzupetnień protetycznych przed ich zacementowaniem $w$ jamie ustnej pacjenta.

Cel pracy. Celem pracy byta kontrola szczelności brzeżnej i dopasowania uzupetnień protetycznych wykonanych $w$ warunkach in vitro.

Material i metody. Materiat do badań stanowity podbudowy koron protetycznych, podzielone na 3 grupy w zależności od zastosowanego materiatu: grupa I- 3 korony z tlenku cyrkonu $\mathrm{ZrO}$, grupa II - 3 korony metalowe ze stopu kobaltowo - chromowego CoCr, grupa III - 3 korony z polimetakrylanu metylu PMMA. Model zęba filarowego oraz modele wewnętrznych powierzchni koron przetransferowano do oprogramowania pomiarowego. Kolejnym krokiem byta analiza doktadności spasowania catej powierzchni wewnętrznej koron z modelem pierwotnym.

Wyniki. W grupie I uzyskano najmniejsze odchylenie standardowe $(0,02 \mathrm{~mm})$, jednak przestrzeń na cement okazała się znacznie większa niż 
same mean was obtained as for Group I, and the discrepancy in the results was the greatest in this group.

Conclusions. The use of reverse engineering methods enables a back control of the correctness of laboratory procedures. Crowns made of zirconium oxide are characterized by the lowest variability of the obtained results, which makes them suitable to be widely used in the clinical practice. Crowns made of cobalt-chrome alloy have the average cement space closest to the original design, which ensures high marginal fit.

\section{Introduction}

Reverse engineering is the process of studying physical, real objects by placing them in a virtual environment. ${ }^{1}$ In the context of dental prosthetics, the most common form of this type of engineering is scanning of impressions and models in a technical laboratory or intraoral scanning of the structures of the patient's oral cavity. The next step is the planning, designing and implementation of prosthetic treatment by making prosthetic restorations. ${ }^{2.3}$ Another application of reverse engineering may be the inspection of completed prosthetic restorations prior to their placement in the patient's oral cavity. Since it is possible to accurately scan both the patient's models and the surface of the prosthetic restoration using high-resolution laboratory scanners, we can now check the fitting parameters and marginal tightness of the prosthetic restoration without the participation of the patient. Thanks to this additional verification, both the dental technician and the dentist can projektowana (średnia 0,09 $\mathrm{mm}$ ). Grupa II charakteryzowata się średnia najbardziej zbliżona do zakładanej (0,06 mm), jednak jej zróżnicowanie było wyraźnie większe niż w przypadku grupy I. Dla grupy III uzyskano taka sama średnia jak dla grupy I, przy czym rozbieżność wyników była w tej grupie największa.

Wnioski. 1. Zastosowanie inżynierii odwrotnej pozwala na pierwsza kontrole poprawności realizacji procedur laboratoryjnych podczas wykonawstwa uzupetnień protetycznych. 2. Korony wykonane z tlenku cyrkonu charakteryzuja sie najmniejsza zmiennościa uzyskanych wyników dopasowania do filaru, co pozwala na ich szerokie zastosowanie w praktyce klinicznej. 3. Korony wykonane ze stopu kobaltowo - chromowego posiadaja średnia przestrzeń na cement najbardziej zbliżona do pierwotnego projektu, co sprawia, że pozwalaja one na wykonanie pracy o wysokiej szczelności.

\section{Wstęp}

Odwrotna inżynieria jest procesem badania fizycznych, rzeczywistych przedmiotów poprzez ich wprowadzenie do środowiska wirtualnego. ${ }^{1} \mathrm{~W}$ kontekście protetyki stomatologicznej najczęstszą formą tego rodzaju inżynierii jest skanowanie wycisków i modeli w laboratorium technicznym lub skanowanie wewnątrzustne struktur jamy ustnej pacjenta. Kolejnym krokiem jest planowanie, projektowanie i realizacja leczenia protetycznego przez wykonanie uzupełnień protetycznych. ${ }^{2,3}$ Innym zastosowaniem odwrotnej inżynierii może być kontrola wykonanych uzupełnień protetycznych przed ich zacementowaniem w jamie ustnej pacjenta. ${ }^{4}$ Dzięki możliwości dokładnego skanowania zarówno modeli pacjenta, jak i powierzchni uzupełnienia protetycznego przy użyciu skanerów laboratoryjnych o wysokiej rozdzielczości, możliwe jest skontrolowanie parametrów dopasowania i szczelności brzeżnej uzupełnienia protetycznego bez 
receive valuable information on the quality of the work performed from the moment of obtaining the model, virtual or real, to the fabrication of a ready-made prosthetic restoration. Successful verification by obtaining the desired parameters confirms the correctness of the laboratory stage in the manufacturing of crowns, bridges and other permanent restorations. In the procedure proposed by the author, marginal fit and the matching of the prosthetic restoration to the abutment tooth are the main parameters to verify. Many authors emphasize their importance from the point of view of the prevention of development of secondary caries under the restoration or the prevention of debonding, and thus ensuring the long-term survival of this type of work. ${ }^{5}$ For this reason, these parameters were considered to be the most important in the initial stage of reverse engineering verification. In order to make prosthetic restorations, it is possible to use many materials. Over the years, one of the most frequently used for crowns was the combination of a metal alloy substructure with porcelain. Thanks to the use of durable and easy-to-machine alloys, it was possible to perform work that meets clinical requirements. Currently, an alternative to such solutions is all-ceramic crowns, including those made of zirconium dioxide, which is characterized by high biocompatibility and good aesthetics. In the fabrication of temporary crowns, polymethyl methacrylate (PMMA) is widely used, which, thanks to sufficient mechanical and aesthetic properties, protects the abutment teeth in the transitional stages during occlusion reconstructions, during orthodontic treatment and in other situations where it is advisable to postpone the fixation of the target restoration.

\section{Aim of the study}

The aim of the study was to evaluate the marginal fit of prosthetic restorations made in vitro. udziału pacjenta. Dzięki tej dodatkowej weryfikacji zarówno technik dentystyczny, jak i lekarz protetyk uzyskują cenne informacje dotyczące jakości wykonanej pracy od momentu uzyskania modelu pacjenta, wirtualnego lub rzeczywistego, aż do wyprodukowania gotowego uzupełnienia protetycznego. Pomyślna weryfikacja i uzyskanie pożądanych parametrów stanowi potwierdzenie poprawności realizacji etapu laboratoryjnego w wykonawstwie koron, mostów i innych stałych uzupełnień. W proponowanym przez autora pracy postępowaniu, szczelność brzeżna i stopień dopasowania uzupełnienia protetycznego do zęba filarowego są głównymi parametrami poddawanymi weryfikacji. Wielu autorów podkreśla ich istotność z punktu widzenia prewencji powstawania próchnicy wtórnej pod uzupełnieniem, czy zapobieganiu odcementowaniu, a co za tym idzie, długoczasowej przeżywalności tego typu prac. ${ }^{3,5} \mathrm{Z}$ tego powodu, uznano właśnie te parametry, jako najważniejsze na początkowym etapie weryfikacji metodą inżynierii odwrotnej. W celu wykonania uzupełnień protetycznych, możliwe jest wykorzystanie wielu materiałów. Przez lata jednym z najczęściej stosowanych w wykonawstwie koron było połączenie podbudowy ze stopu metali z porcelaną. Dzięki użyciu wytrzymałych i łatwych w obróbce stopów możliwe było wykonywanie prac spełniających wymagania kliniczne. Alternatywą dla takich rozwiązań są obecnie korony pełnoceramiczne, w tym wykonywane z dwutlenku cyrkonu, który charakteryzuje się dużą biozgodnością i dobrą estetyką. W wykonawstwie koron tymczasowych szerokie zastosowanie ma polimetakrylan metylu (PMMA), który dzięki wystarczającym właściwościom mechanicznym i estetycznym, pozwala na zabezpieczenie zębów filarowych w etapach przejściowych przy rekonstrukcjach zwarcia, podczas leczenia ortodontycznego i w innych sytuacjach, gdzie wskazane jest odroczenie wykonania docelowego uzupełnienia. 


\section{Material and methods}

The material consisted of prosthetic crown substructures, divided into three groups:

- Group I - three zirconium oxide $\left(\mathrm{ZrO}_{2}\right)$ crowns,

- Group II - three metal crowns made of a cobalt-chromium $(\mathrm{CoCr})$ alloy,

- Group III - three crowns made of polymethyl methacrylate (PMMA).

Each crown was made on the basis of a laboratory scan of the prepared model, with the upper canine prepared for the prosthetic crown in accordance with the applicable rules. The model was printed on a 3D printer using abrasion-resistant material to prevent damage to the surface, which is a reference for further measurements (Fig. 1) One common

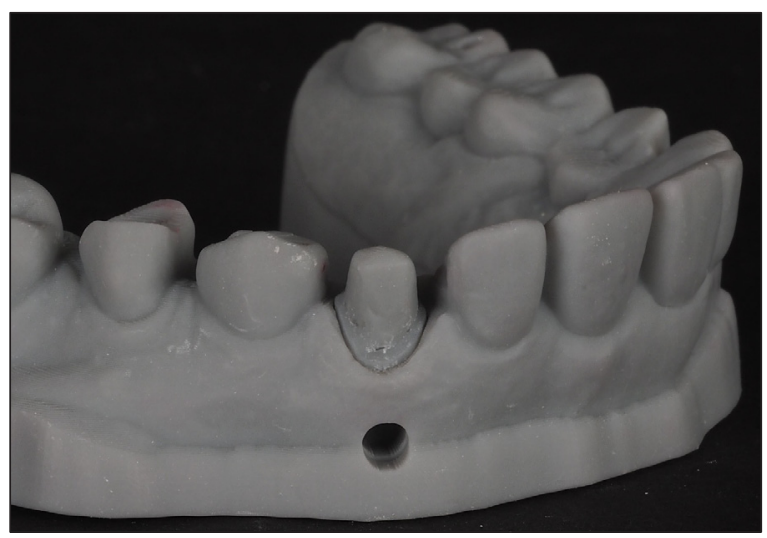

Fig. 1. 3D printed cast.

Ryc. 1. Wydrukowany model referencyjny.

framework design for a single prosthetic crown was prepared, and then the milling strategy for individual restorations was programmed, taking into account the characteristics of the material from which they are to be made. Within the step, a zero space value was designed, while in the rest of the crown, a minimum space for the cement of $0.05 \mathrm{~mm}$ was planned, increasing only in situations where it would be impossible to carry out the correct milling process. After the crowns were made (Figs. 2-7), they were placed

\section{Cel pracy}

Celem pracy była kontrola szczelności brzeżnej i dopasowania uzupełnień protetycznych wykonanych $\mathrm{w}$ warunkach in vitro.

\section{Material i metoda}

Materiał do badań stanowily podbudowy koron protetycznych, podzielone na 3 grupy w zależności od zastosowanego materiału:

- grupa I - 3 korony z tlenku cyrkonu $\mathrm{ZrO}_{2}$,

- grupa II - 3 korony metalowe ze stopu kobaltowo-chromowego $\mathrm{CoCr}$,

- grupa III - 3 korony z polimetakrylanu metylu PMMA.

Każda korona została wykonana na podstawie skanu laboratoryjnego przygotowanego modelu, z opracowanym górnym kłem do korony protetycznej zgodnie $\mathrm{z}$ obowiązującymi zasadami. Model został wydrukowany w drukarce 3D z odpornego na ścieranie materiału, aby zapobiec uszkodzeniu powierzchni, stanowiącej punkt odniesienia do dalszych pomiarów (ryc. 1) Wykonano jeden wspólny projekt podbudowy pojedynczej korony protetycznej, a następnie zaprogramowano strategię frezowania poszczególnych uzupełnień, uwzględniając charakterystykę materiału, z jakiego mają być wykonane. W obrębie stopnia zaprojektowano zerową wartość przestrzeni, natomiast $\mathrm{w}$ pozostałej części korony zaprojektowano minimalną przestrzeń dla cementu o wartości 0,05 $\mathrm{mm}$, zwiększając ją jedynie w przypadkach, gdy niemożliwe byłoby przeprowadzenie poprawnego procesu frezowania. Po wykonaniu koron (ryc. 2-4), zostały one wprowadzone na model w celu makroskopowej oceny poprawności ich wykonania (ryc. 5-7). Powierzchnia wewnętrzna koron została poddana procesowi skanowania laboratoryjnego w celu uzyskania chmury punktów, a następnie modelu CAD, odpowiadającemu gotowemu uzupełnieniu protetycznemu. Model zęba filarowego oraz modele 

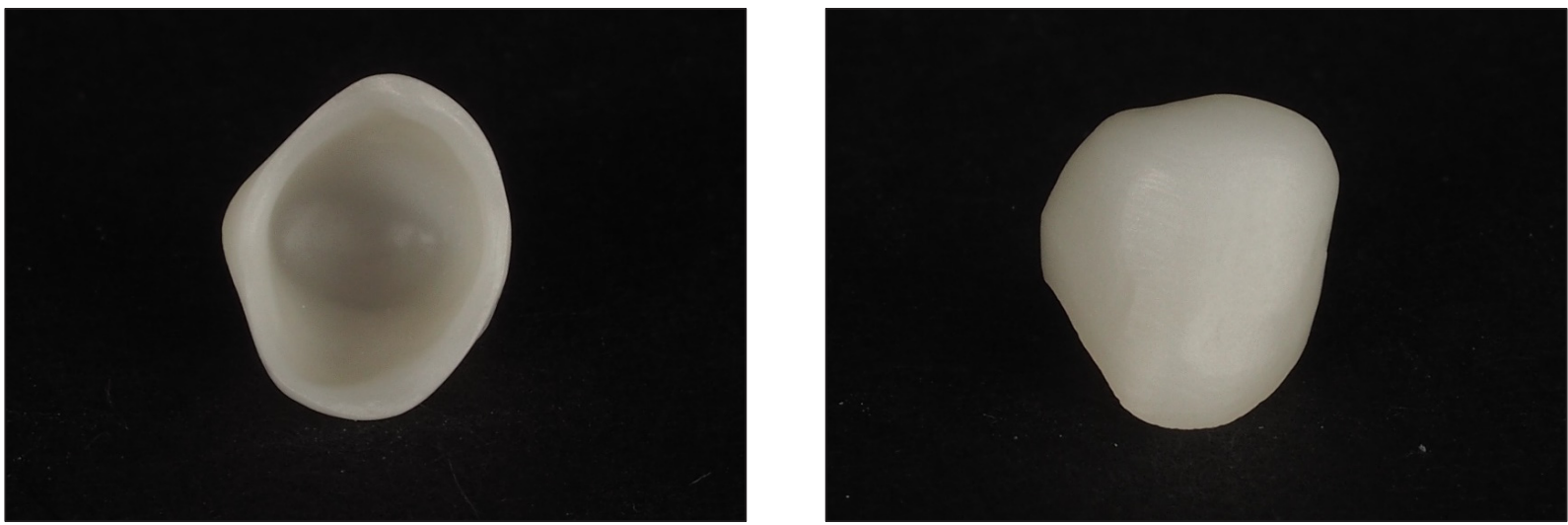

Fig. 2. Zirconium dioxide frameworks.

Ryc. 2. Podbudowy z tlenku cyrkonu.
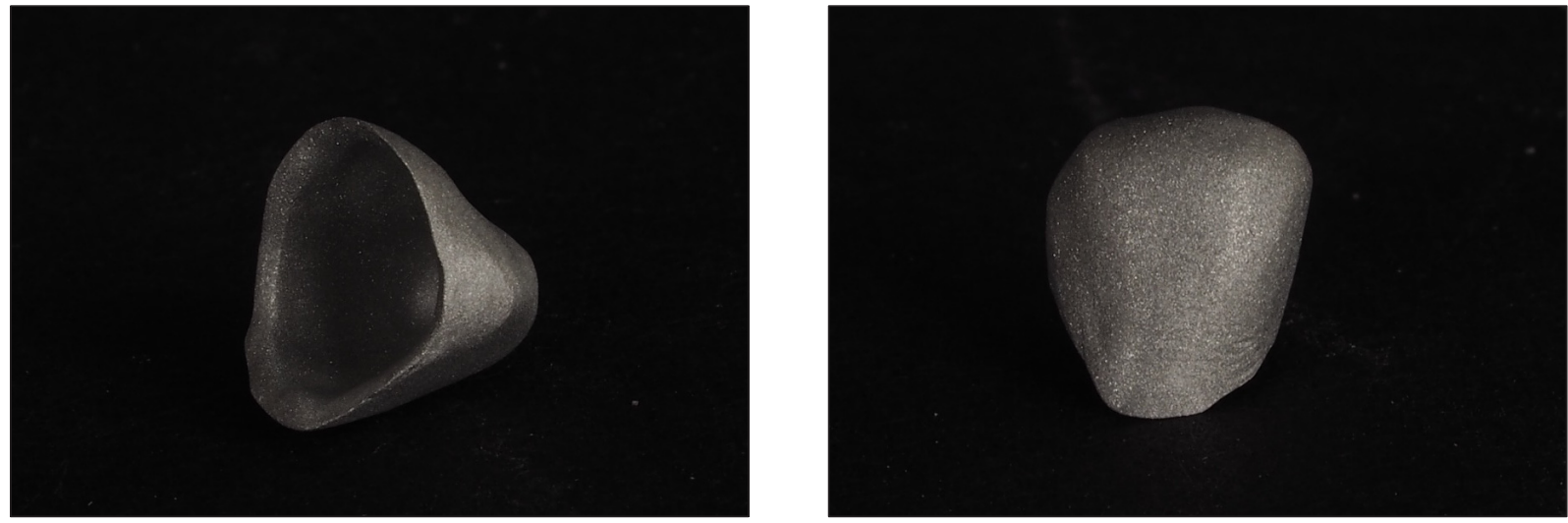

Fig. 3. Frameworks made of cobalt-chrome alloy.

Ryc. 3. Podbudowy ze stopu kobaltowo-chromowego.
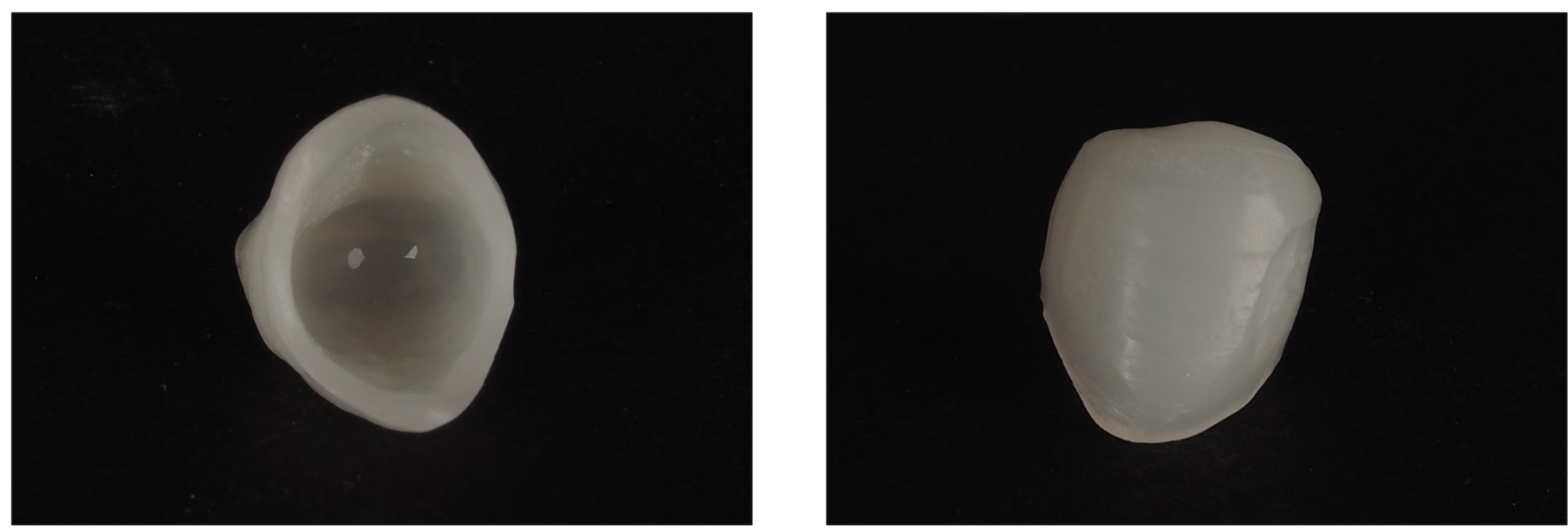

Fig. 4. Frameworks made of PMMA polymethyl methacrylate.

Ryc. 4. Podbudowy z polimetakrylanu metylu PMMA.

on the model for macroscopic evaluation of their correctness (Figs. 8-10). The inner surface of the crowns was subjected to a laboratory scanning process first in order to obtain a point cloud, and then a CAD model, corresponding wewnętrznych powierzchni koron przetransferowano do oprogramowania pomiarowego GOM Inspect 2018 (GOM GmbH, Niemcy). Kolejnym krokiem była analiza dokładności spasowania całej powierzchni wewnętrznej 


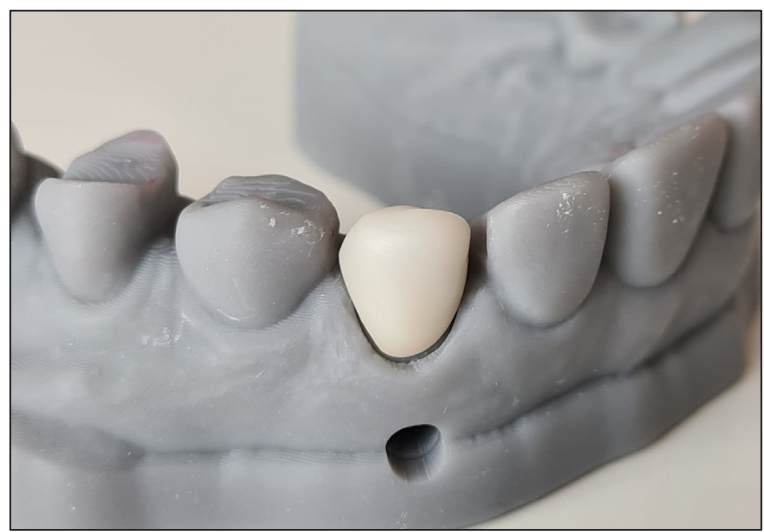

Fig. 5. Model control of the zirconium oxide framework.

Ryc. 5. Kontrola na modelu podbudowy z tlenku cyrkonu.

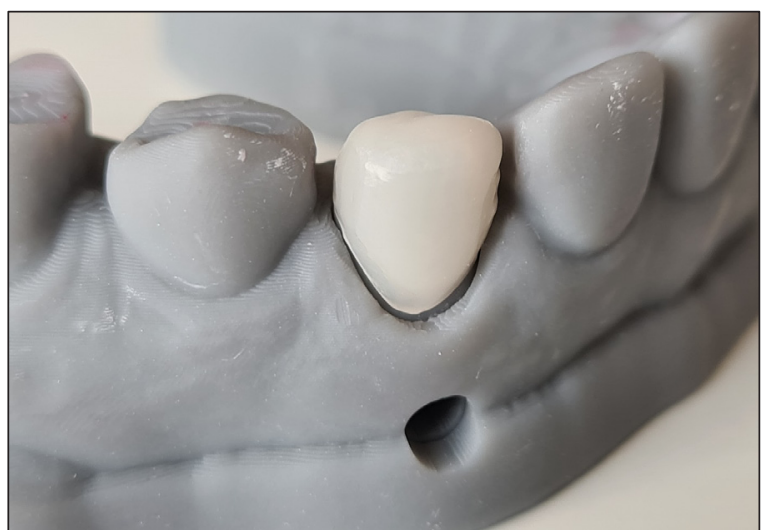

Fig. 7. Model control of polymethyl methacrylate framework.

Ryc. 7. Kontrola na modelu podbudowy z polimetaktylanu metylu.

to the finished prosthetic restoration. The abutment tooth model and the models of the internal surfaces of the crowns were transferred to the GOM Inspect 2018 measuring software (GOM GmbH, Germany). The next step was to analyse the accuracy of fitting of the entire inner surface of the crowns on the original model. For this purpose, the Local Best Fit command was used, marking the area of all the walls of the abutment tooth. In order to properly orient the reference model and the crown framework spatially, it was necessary to rotate the spatial vectors of the grids of the points of the scanned crowns. The obtained results were presented

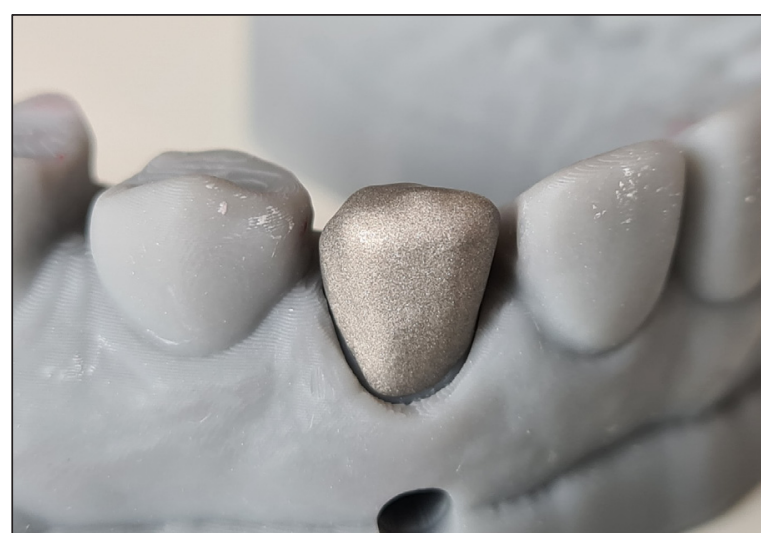

Fig. 6. Model control of a cobalt-chrome alloy framework.

Ryc. 6. Kontrola na modelu podbudowy ze stopu kobaltowo-chromowego.

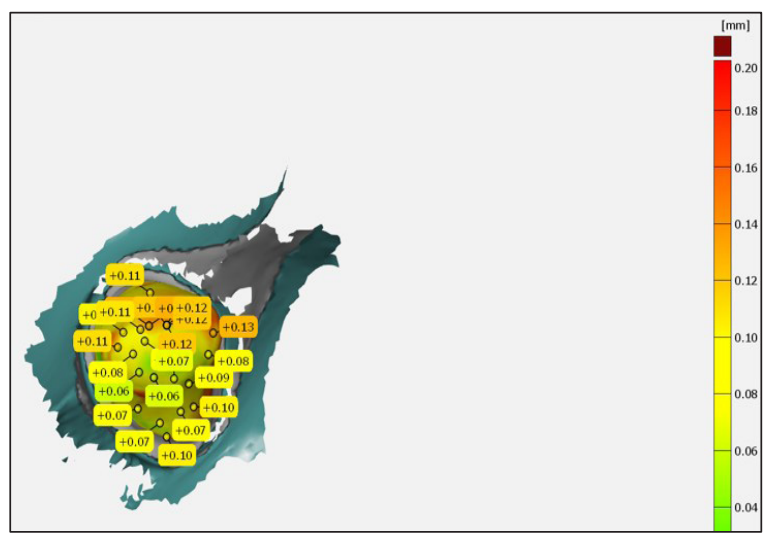

Fig. 8. Measurement of the fit of the zirconium oxide framework.

Ryc. 8. Pomiar dopasowania podbudowy z tlenku cyrkonu.

koron z modelem pierwotnym. W tym celu zastosowano komendę Local Best Fit, zaznaczając obszar wszystkich ścian zęba filarowego. Aby właściwe zorientować przestrzennie model referencyjny i podbudowy koron, konieczne było obrócenie wektorów przestrzennych siatek punktów zeskanowanych koron. Uzyskane wyniki przedstawiono w formie graficznej, jak również w sposób losowy zaznaczono 20 punktów pomiarowych dla każdej korony w celu liczbowego określenia uzyskanych danych. Wykonano analizę statystyczną uzyskanych wyników w oprogramowaniu Statistica, określając wartości statystyki opisowej. 


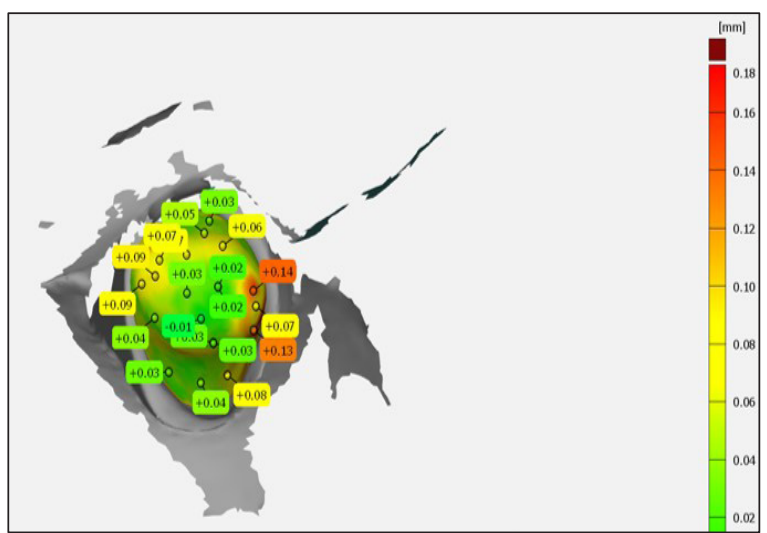

Fig. 9. Measurement of the fit of a cobalt-chrome alloy framework.

Ryc. 9. Pomiar dopasowania podbudowy ze stopu kobaltowo-chromowego.

in a graphic form, as well as randomly marked twenty measurement points for each crown in order to quantify the obtained data. Statistical analysis of the obtained results was performed in the Statistica software, determining the values of descriptive statistics.

\section{Results}

The results presented in Table 1 were obtained on the basis of the study. The reference value according to the crown design is $0.05 \mathrm{~mm}$, corresponding to the space provided for the luting cement. In Group I, the lowest standard deviation was obtained $(0.02 \mathrm{~mm})$, but the space for the cement turned out to be much larger than the designed space (average $0.09 \mathrm{~mm}$ ). Group II was characterized by the mean closest to the assumed one $(0.06 \mathrm{~mm})$, but its differentiation was clearly greater than in the case of Group I, which is illustrated by the comparison of Figures 8 and 9 and the increased value of the standard deviation $(0.03 \mathrm{~mm})$. For Group III, the same mean was obtained as for Group I, but the discrepancy in the results was the greatest in this group - the standard deviation was 0.04 $\mathrm{mm}$, while the analysis of Figures 10 and 11 indicates a large variability of the obtained fit

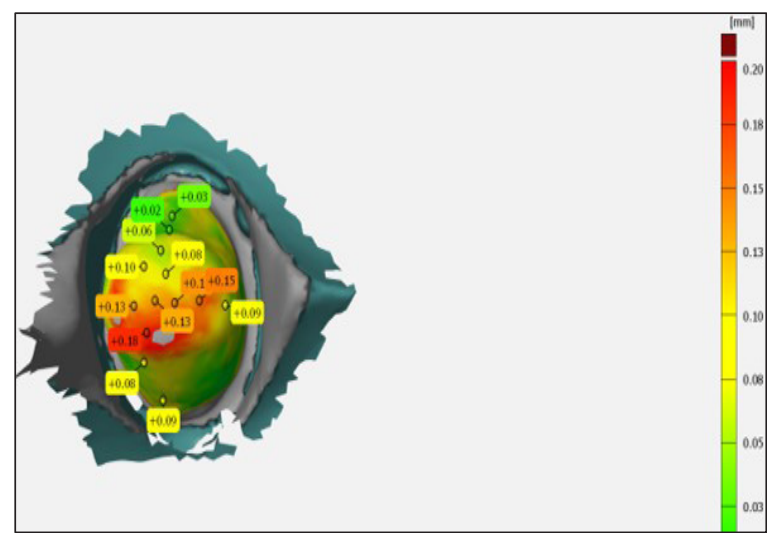

Fig. 10. Measurement of the fit of a polymethyl methacrylate framework.

Ryc. 10. Pomiar dopasowania podbudowy z polimetakrylanu metylu.

\section{Wyniki}

$\mathrm{Na}$ podstawie przeprowadzonego badania uzyskano wyniki przedstawione w tabeli 1 . Wartością referencyjną, zgodną z projektem koron jest $0,05 \mathrm{~mm}$, odpowiadającą przewidzianej przestrzeni na cement. W grupie I uzyskano najmniejsze odchylenie standardowe $(0,02 \mathrm{~mm})$, jednak przestrzeń na cement okazała się znacznie większa niż projektowana (średnia 0,09 mm). Grupa II charakteryzowała się średnią najbardziej zbliżoną do zakładanej $(0,06 \mathrm{~mm})$, jednak jej zróżnicowanie było wyraźnie większe niż w przypadku grupy I, co ilustruje porównanie rycin 8 i 9 oraz zwiększona wartość odchylenia standardowego $(0,03 \mathrm{~mm})$. Dla grupy III uzyskano taką samą średnią jak dla grupy I, przy czym rozbieżność wyników była w tej grupie największa - odchylenie standardowe wyniosło 0,04 $\mathrm{mm}$, natomiast analiza ryciny $10 \mathrm{i} 11 \mathrm{wskazuje}$ dużą zmienność uzyskanego dopasowania dla tej grupy koron. Co więcej, w grupie III odnotowano największą ze wszystkich grup wartość pojedynczego obszaru równą $0,18 \mathrm{~mm}$, co stanowi ponad trzykrotność zakładanej wartości referencyjnej. 
Ta b le 1. Descriptive statistics of crown fit values results (mm)

\begin{tabular}{|l|c|c|c|}
\hline & Group I & Group II & Group III \\
\hline Mean & 0.09 & 0.06 & 0.09 \\
\hline Standard deviation & 0.02 & 0.03 & 0.04 \\
\hline Maximal value & 0.13 & 0.14 & 0.18 \\
\hline Minimal value & 0.06 & 0.01 & 0.02 \\
\hline
\end{tabular}

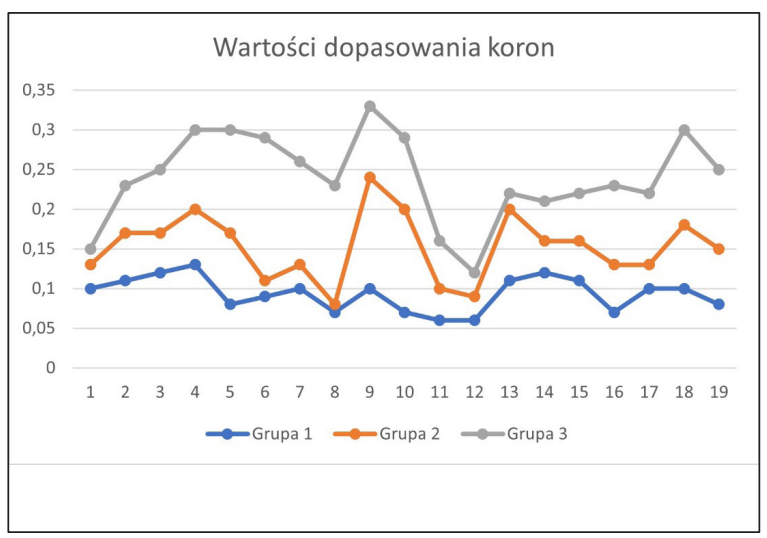

Fig. 11. Crown fit measurement chart.

Ryc. 11. Wykres pomiarów dopasowania koron.

for this group of crowns. Moreover, in Group III, the highest value of a single area of $0.18 \mathrm{~mm}$ was recorded, which is more than three times the assumed reference value.

\section{Discussion}

The presented research results indirectly show the characteristics of the performance of prosthetic restorations made of various materials. The most reproducible results were obtained in the group of zirconium oxide crowns, which correlates with the characteristics of this material - on the one hand, it enables the production of very thin restorations while maintaining very good mechanical parameters, and on the other hand, working with small diameter burs is possible. 6,7 Substructures made of cobalt-chrome alloy

\section{Dyskusja}

Przedstawione wyniki badania pokazują $\mathrm{w}$ sposób pośredni charakterystykę wykonawstwa uzupełnień protetycznych z różnych materiałów. Najbardziej powtarzalne wyniki uzyskano $\mathrm{w}$ grupie koron wykonanych z tlenku cyrkonu, co koreluje $\mathrm{z}$ charakterystykę tego materiału $-\mathrm{z}$ jednej strony pozwala on na wykonywanie bardzo cienkich uzupełnień przy zachowaniu bardzo dobrych parametrów mechanicznych, a z drugiej pozwala na pracę frezami o niewielkiej średnicy. Podobne wyniki uzyskano w innych badaniach, w których korony wykonane z dwutlenku cyrkonu charakteryzowały się najlepszą szczelnością brzeżną. ${ }^{6,7}$ Podbudowy ze stopu kobaltowo - chromowego wymagają użycia frezów o większej średnicy, a co za tym idzie, nie pozwala na tak precyzyjne odwzorowanie pierwotnego projektu, jednak średnia wartość pokazuje, że w korzystnych warunkach z tego materiału możliwe jest dokładne frezowanie podbudowy. ${ }^{8} \mathrm{Z}$ kolei materiał PMMA, przeznaczony do wykonywania uzupełnień tymczasowych, oprócz oczywistych gorszych parametrów mechanicznych, również okazuje się materiałem, który uzyskał największą zmienność parametrów dopasowania, co przekłada się na kliniczne zmniejszenie szczelności takiego uzupełnienia. W badaniach dostępnych w piśmiennictwie, autorzy wskazują jednak na zdecydowaną poprawę jakości dopasowania uzupełnień tymczasowych wykonanych w technologii CAD $\backslash \mathrm{CAM}$ w porównaniu z innymi metodami. 9,10 
require the use of milling burs with a larger diameter, and thus do not permit such a precise reproduction of the original design, but the average value shows that under favourable conditions, this material can be accurately milled. ${ }^{8}$ On the other hand, PMMA, intended for temporary restorations, having the obvious worse mechanical parameters, also turns out to be the material that has obtained the greatest variability of the fit parameters, which translates into a clinical reduction in the tightness of such a restoration. However, in the studies available in the literature, the authors indicate a significant improvement in the quality of fitting of temporary restorations made in the CAD/CAM technology compared to other methods. ${ }^{9,10}$ In the proposed procedure, the subsequent inspection in the oral cavity, showing irregularities in the marginal tightness and fitting, allows excluding their potential causes resulting from errors at the stage of designing or performing laboratory prosthetic work. This is valuable information that enables easy location of the problem. Moreover, the analysis of a larger number of cases may lead to the improvement of laboratory and clinical procedures and the elimination of potential errors. Such a procedure may be particularly useful in the academic centers, where many activities are carried out as part of undergraduate training. In addition, the didactic aspect is the ability to follow one's clinical procedure, analyse the correctness of individual stages and go back to the revealed error, and then try to redo the prosthetic work. Such procedures seem to be an effective form of training clinical work capacity. In the presented study, the verified features were marginal fit and the degree of matching of the crown to the abutment tooth. The system for assessing these parameters seems to be the most repeatable and unambiguous to be implemented. This is due to the small number of elements that are subject to mutual
W proponowanej metodzie postępowania, następowa kontrola w jamie ustnej wykazująca nieprawidłowości w obrębie szczelności brzeżnej i dopasowania, pozwala na wykluczenie potencjalnych przyczyn wynikających z błędów na etapie projektowania lub wykonania laboratoryjnego pracy protetycznej. Jest to cenna informacja, pozwalająca na łatwe zlokalizowanie problemu. Co więcej, analiza większej liczby przypadków może doprowadzić do doskonalenia procedur laboratoryjnych i klinicznych oraz eliminowania pojawiających się błędów. Takie postępowanie może być szczególnie przydatne w ośrodkach akademickich, gdzie wiele czynności realizowanych jest w ramach szkolenia przeddyplomowego, dlatego aspektem dydaktycznym jest możliwość prześledzenia własnego postępowania klinicznego, analiza poprawności poszczególnych etapów i możliwość cofnięcia się do wychwyconego błędu, a następnie próba wykonania pracy protetycznej na nowo. Takie postępowanie wydaje się skuteczną formą kształcenia zdolności pracy klinicznej.

W przedstawionym badaniu cechami poddawanymi weryfikacji były szczelność brzeżna i stopień dopasowania korony do zęba filarowego. Układ oceny tych parametrów wydaje się najbardziej powtarzalnym i jednoznacznym do realizacji. Wynika to $\mathrm{z}$ niewielkiej liczby elementów poddawanych wzajemnym pomiarom (układ ząb - korona), jak i łatwości we wskazaniu interesujących badacza obszarów, które należy ze sobą porównać. Jednak zastosowanie tej metody może również posłużyć do analizy znacznie bardziej skomplikowanego układu, jakim jest badanie zwarcia, w jakim finalnie ma być zlokalizowana wykonywana praca protetyczna. W takim założeniu, punktami odniesienia powinny być zęby przeciwstawne, zlokalizowane w ściśle określonym miejscu w przestrzeni względem zęba filarowego oraz powierzchnia okluzyjna korony protetycznej. Zastosowanie przedstawionej 
measurements (the tooth-crown system), as well as the ease in identifying areas of interest to the researcher that should undergo comparison. However, this method can also be used to verify a much more complicated system, namely the examination of the occlusion, which is the target area for the prosthetic work. In such a case, the opposing teeth located in a strictly defined space in relation to the abutment tooth, and the occlusal surface of the prosthetic crown, should constitute the reference points.. The presented procedure enables the construction of such a system and taking appropriate measurements aimed at locating the place and surface of the future contact in a static occlusion. The next step is the analysis of the dynamic occlusion, but the correct recording and subsequent mapping of the patient's mandibular movement requires a significant extension of the presented method with additional tests and modification of the measurement procedure.

It should be noted that the presented study concerns the analysis of the quality of laboratory procedures and the obtained results are not affected by aspects of clinical work - the verification of the prosthetic restoration itself is carried out in the same way on a model specially prepared for the in vitro study and in clinical work. However, in order to verify the usefulness of the obtained results in the context of the clinical application of the described method, it is advisable to compare the obtained data on the tested prosthetic restorations made for patients with their control in the oral cavity. The use of reverse engineering is one of several methods of marginal tightness measurement described in the literature. Unlike microtomography, it uses the measuring tools available in a standard prosthetic laboratory. In turn, in comparison with the technique of micro-impressions, the quantitative evaluation of the obtained results is much easier. ${ }^{4,11}$ procedury pozwala na skonstruowanie takiego układu i wykonanie stosownych pomiarów, mających na celu zlokalizowanie miejsca i powierzchni przyszłego kontaktu w zwarciu statycznym. Kolejnym krokiem jest analiza zwarcia dynamicznego, jednak poprawne zarejestrowanie, a następnie odwzorowanie indywidualnego ruchu żuchwy pacjenta wymaga znacznego rozszerzenia przedstawionej metody o dodatkowe badania oraz modyfikację procedury pomiarowej.

Należy zwrócić uwagę, że przedstawione badanie dotyczy analizy jakości procedur laboratoryjnych i na uzyskane wyniki nie wpływają aspekty pracy klinicznej - sama weryfikacja uzupełnienia protetycznego przebiega $\mathrm{w}$ ten sam sposób na przygotowanym specjalnie do przeprowadzenia badania in vitro modelu, jak i w pracy klinicznej. Jednak aby zweryfikować przydatność uzyskanych wyników w kontekście zastosowania klinicznego opisanej metody, wskazane jest porównanie uzyskanych danych dotyczących badanych uzupełnień protetycznych wykonanych dla pacjentów z ich kontrolą w jamie ustnej.

Zastosowanie odwrotnej inżynierii jest jedną z kilku opisywanych w piśmiennictwie metod pomiaru szczelności brzeżnej. W przeciwieństwie do mikrotomografii, wykorzystuje ona narzędzia pomiarowe znajdujące się w wyposażeniu standardowego laboratorium protetycznego. Z kolei w porównaniu do techniki wykonywania mikrowycisków, pozwala na łatwiejszą oceną liczbową uzyskanych wyników. ${ }^{4,11}$

\section{Wnioski}

1. Zastosowanie metod inżynierii odwrotnej pozwala na pierwszą kontrolę poprawności realizacji procedur laboratoryjnych podczas wykonawstwa uzupełnień protetycznych.

2. Korony wykonane z tlenku cyrkonu charakteryzują się najmniejszą zmiennością 


\section{Conclusions}

1. The use of reverse engineering methods permits a back control of the correctness of laboratory procedures during the fabrication of prosthetic restorations.

2. Crowns made of zirconium oxide are characterized by the lowest variability of the obtained results of matching to the abutment tooth, which is an argument for their general use in the clinical practice

3. Crowns made of cobalt-chrome alloy have the average cement space closest to the original design, due to which work can be performed with high marginal fit. uzyskanych wyników dopasowania do filaru, co pozwala na ich szerokie zastosowanie w praktyce klinicznej.

3. Korony wykonane ze stopu kobaltowo-chromowego posiadają średnią przestrzeń na cement najbardziej zbliżoną do pierwotnego projektu, co sprawia, że pozwalają one na wykonanie pracy o wysokiej szczelności.

\section{References / Piśmiennictwo}

1. Várady T, Martin RR, Cox J: Reverse engineering of geometric models - an introduction, Computer-Aided Design 1997; 29, 4: 255-268. ISSN 0010-4485, https://doi. org/10.1016/S0010-4485(96)00054-1.

2. Beuer F, Schweiger J, Edelhoff D: Digital dentistry: an overview of recent developments for $\mathrm{CAD} / \mathrm{CAM}$ generated restorations. $\mathrm{Br}$ Dent J 2008; 204(9): 505-511.

3. Kim TG, Kim S, Choi H, Lee JH, Kim JH, Moon HS: Clinical Acceptability of the Internal Gap of CAD/CAM PD-AG Crowns Using Intraoral Digital Impressions. Biomed Res Int 2016; 2016: 7065454.

4. Jang Y, Sim JY, Park JK, Kim WC, Kim HY, Kim JH: Evaluation of the marginal and internal fit of a single crown fabricated based on a three-dimensional printed model. J Adv Prosthodont 2018; 10(5): 367-373. doi: 10.4047/jap.2018.10.5.367. Epub 2018 Oct 22. PMID: 30370028; PMCID: PMC6202428.

5. Dahl BE, Dahl JE, Rønold HJ: Digital evaluation of marginal and internal fit of single-crown fixed dental prostheses. Eur J Oral Sci 2018; 126(6): 512-517. doi: 10.1111/eos.12576. Epub 2018 Oct 8. PMID: 30298624.

6. Hamza TA, Ezzat HA, El-Hossary MK, Katamish HM, Shokry TE, Rosenstiel SF: Accuracy of ceramic restorations made with two CAD/CAM systems. J Prosthet Dent 2013; 109(2): 83-87.

7. Schriwer C, Skjold A, Gjerdet NR, Øilo M: Monolithic zirconia dental crowns. Internal fit, margin quality, fracture mode and load at fracture. Dent Mater 2017; 33(9): 1012-1020. doi: 10.1016/j.dental.2017.06.009. Epub 2017 Jun 26. PMID: 28662859.

8. Paul N, Raghavendra Swamy KN, Dhakshaini $M R$, Sowmya $S$, Ravi MB: Marginal and internal fit evaluation of conventional metalceramic versus zirconia CAD/CAM crowns. J Clin Exp Dent 2020; 12(1): e31-e37. doi: 10.4317/medoral.55946. PMID: 31976041; PMCID: PMC6969964.

9. Chaturvedi S, Alqahtani NM, Addas $M K$, 
Alfarsi MA: Marginal and internal fit of provisional crowns fabricated using 3D printing technology. Technol Health Care 2020; 28(6): 635-642. doi: 10.3233/THC191964. PMID: 32280071.

10. Abdullah AO, Tsitrou EA, Pollington S: Comparative in vitro evaluation of $\mathrm{CAD} /$ CAM vs conventional provisional crowns. J Appl Oral Sci 2016; 24(3): 258-263. doi: 10.1590/1678-775720150451. PMID: 27383707 ; PMCID: PMC5022219.
11. Pimenta MA, Frasca LC, Lopes R, Rivaldo $E$ : Evaluation of marginal and internal fit of ceramic and metallic crown copings using x-ray microtomography (micro-CT) technology. J Prosthet Dent 2015; 114(2): 223228. doi: 10.1016/j.prosdent.2015.02.002. Epub 2015 Apr 14. PMID: 25882975.

Zaakceptowano do druku: 25.08.2021 r.

Adres autorów: 02-097 Warszawa, ul. Binieckiego 6.

C) Zarząd Główny PTS 2021. 